\title{
BIODIVERSITY OF SOIL MITES ASSOCIATED WITH WHEAT AND SOYBEAN CROPS IN SHARKEIA AND BEHEIRA GOVERNORATES
}

\author{
FATMA SH. KALMOSH and E.M.A. YASSIN
}

Cotton and Field Crops Mites Res. Dept., Plant Protection Rresearch Institute, A.R.C., Dokki, Giza, Egypt. Corresponding author: Bkalmosh@yahoo.com

(Manuscript received 3 April 2018)

\begin{abstract}
$\mathrm{B}$ iodiversity of different soil mite associated with both wheat and soybean crops surveyed in Sharkeia and Beheira governorates during two successive seasons 2016 and 2017. Fifty-seven mite species belonging to 41 genera under 22 families belonging to four sub-orders; Mesostigmata, Prostigmata, Cryptostigmata and Astigmata were identified. The total numbers of the collected mite groups recorded 69, 295, 533 and 602 individuals for Astigmata, Mesostigmata, Cryptostigmata and Prostigmata in Sharkeia, while the number of mites recorded 104, 378, 282 and 405 individuals for the previous groups in Beheira, respectively. Soil mites associated with wheat crop were higher numbers than soil mites of soybean. The oribatid and mesostigmatid mite species exhibite the higher number of soil mites in soil wheat followed by prostigmatid and astigmatid, while the low number of mites were recorded in soil cultivated by soybean plants.
\end{abstract}

Keywords: Biodiversity, soil mites, wheat, soybean.

\section{INTRODUCTION}

Mites are widespread in every sort of aquatic, arboreal, terrestrial and parasitic habitat, which accounting for as much as $80 \%$ of all soil arthropods commuting living in the soil (Peterson and Luxton, 1982; Minor and Norton, 2004). They are not passive inhabitants of ecosystem. In fact, they are strong interactors with other organisms. In a similar way they are important indicators of disturbance in both aquatic and terrestrial systems and they are a major component of biological diversity. Functionally, they are classified as engineers of soil structure, indicators of the health of soil systems and major interactors with nematodes and microbes in decomposition (Walter and Proctor, 1999). Soil is an important component for monitoring of sustainability of land use in relation to both the conservation of natural resources and biodiversity of ecosystems. So, it has been growing awareness of species diversity and growing interest in understanding the factors influencing soil biodiversity (Ducarme and Lebrun, 2004). However plants play a dominant role as the foundation of the food web, so, it has been suggested that plant litter quality, quantity and timing, the soil water balance and microclimate in the surface layer and root 
activity can determine the functioning of the belowground ecosystem (Hairiah et al., 2001). The mesostigmatid mites play important role as predators of other soil microarthropods and both free-living and plant parasitic nematodes (Koehler, 1999; Beaulieu and Walter, 2007). They play a vital role in regulating the pest population in the soil.

So, the objective of this study is to survey the soil mites associated with wheat and soybean crops in Sharkeia and Beheira governorates during two successive seasons 2016 and 2017.

\section{MATERIALS AND METHODS}

\section{Survey of soil mites associated with wheat and soybean plants:}

The present investigation was conducted at two locations in diameter from Sharkeia and Beheira governorates during seasons 2016 and 2017.

To survey the soil mites inhabiting soil cultivated by wheat and soybean crops, $500 \mathrm{~g}$ of soil with three replicates were fortnightly taken using iron cylinder of one cubic liter at depth of $10-\mathrm{cm}$ under the two crops (Gilyarov, 1975). Soil samples were kept in paper bags and transferred to the laboratory, soil samples were extracted using modified Tullgren's funnels (Lasebikan, 1974), allowed to mites fall into small jar containing $75 \%$ ethyl alcohol $+5 \%$ glycerol. Then extracted mites mounted on glass slides in Hoyer's medium for identification. The identification of mites was based on illustrated to the world references keys Krantz and Walter (2009); Zaher (1986) and Evans (1992).

\section{Data analysis:}

The community structure of soil mites was analyzed using abundance and dominance percentage. Species diversity was expressed by the Shannon-Wienner Index $\left(\mathrm{H}^{\prime}\right)$ and the evenness $\left(\mathrm{J}^{\prime}\right)$ was calculated by Pielous $\left(\mathrm{J}^{\prime}\right)$ according to Pielou (1984):

$$
h=-\sum_{j=1}^{x} p_{j} \ln p_{j}
$$

$\mathrm{H}$, Shannon's diversity index

$\mathrm{S}$, total number of species in the community (richness

$\mathrm{Pi}$, proportion of $S$ made up of the th species

$E_{H}$, equitability (evenness)

\section{RESULTS AND DISCUSSION}

\section{Survey of soil mites associated with wheat and soybean plants:}

At the present study, 57 mite species belonging to 41 genera under 22 families from four mite sub-orders were collected, (Table 1). Sub-order Mesostigmata 
was represented by nine families namely: Ascidae was represented by two species; Arectoseius butleri Hughes and Gamasellodes bicolor Athias-Henriot; family Melicharidae was represented by five species: Proctolaelaps orientalis Naser, P. scolyti Evans, P. holoventris Moraes, Britto, Mineiro \&Halliday, P. pygmaeus (Müller) and $P$. aegyptiacus Naser; family Pachylaelapidae was represented by only mite species namely Pachlaelaps reticulates Berlese; family Blattisociidae represented by eight species: Lasioseius lindquisti Naser and Abou-Awad., L. parberlesei Bhattacharyya, L. aegypticus Afifi, L. africanus Naser, L. pencillinger Naser, Blattisoeius tarsalis Berlese, B. keegani Fox and Blattisoeius mali Oüdemans; family Macrochelidae represented by two species: Macrocheles muscadomesticae (Scopoli) and M. africanus Hafez, ElBadry\&Naser; whereas family Laelapidae represented by six species: Ololaelaps bregetovae Shereef and Soliman, Androlaelaps casalis (Berlese), Hypoaspis sardoa Berlese, $H$. baloghi Shereef and Afifi, $H$. lubrica Voigts \& Oüdemans and Pneumolaelaps lubricus (Oüdemans \& Voigts); family Uropodidae represented by two species, Uroobovells (Fuscuropoda) sp. Krantzi and Chiropturopoda bakeri Zaher\&Afifi, family Digamasellidae and Haemogamasidae were represented by a single species for both of them namely: Digamasellus presepum Berlese and Haemogamasus pontiger (Berlese), respectively.

Sub-order Prostigmata was represented by nine families: Eupodidae was represented by three species: Cocceupodes trandtmanni Abou-Awad and El-Bagoury, Eupodes momeni Abou-Awad and Eupodes voxencollinus Sig Thor; family Rhagiidae was represented by two species: Neothoria niloticus Abou-Awad and El-Bagoury and Roubustocheles mucronata Zacharda; family Badellidae was represented by two species namely Bdellodes longirostris (L.) and Cyta latirostris (Hermann); family Cunaxidae was represented by three species: Cunaxa spp., C. potchensis Den Heyer and Doctyloscirus dolichosctosus Den Heyer; family Chyletidae represented by two species namely: Chyletogenus ornatus (Can. \&Fanz.) and Cheyletus badryi Zaher and Hassan; family Raphignathidae represented by two species: Raphignathus gracilis (Rack) and Raphignathus bakeri Zaher \& Gomaa; family Samarididae was represented by a single specie namely Tichosmaris jacoti (Southcot); family Stigmaeidae represented by six species: Apostigmaeus navicella Grandjean, Ledermuelleriopsis dendrites Willmann, Mediolata aegyptiaca Zaher \& Soliman, M. pentascuta Zaher \& Gomaa, Agistemus banksi Gomaa \& Hassan and A. vulgaris Soliman \& Gomaa; family Tydeidae represented by three species namely Tydeius sp, Paralorryia gizai El Bagoury and Lorrryia reticulate Oüdemans. 
Table 1. A partial taxonomic list of mites inhabiting soil of soybean plants in Sharkeia and Beheira Governorates throughout 2016 season.

\begin{tabular}{|c|c|c|c|c|}
\hline \multirow{2}{*}{$\begin{array}{c}\text { Acari } \\
\text { Sub - order }\end{array}$} & \multirow{2}{*}{ Family } & \multirow{2}{*}{ Mite species } & \multicolumn{2}{|c|}{$\begin{array}{c}\text { Dominance of mite } \\
\text { species }\end{array}$} \\
\hline & & & Sharkeia & Beheira \\
\hline \multirow[t]{28}{*}{ Mesostigmata } & \multirow[t]{2}{*}{ Ascidae } & Arectoseius butleri Hughes & $7.79 *$ & $2.91 *$ \\
\hline & & Gamasellodes bicolor $\mathrm{A} .-\mathrm{H}$. & 3.05 & 1.85 \\
\hline & \multirow{5}{*}{$\begin{array}{l}\text { Melicharidae } \\
\text { Hirschmann }\end{array}$} & Poctolaelaps orientalis Naser & 4.75 & 1.06 \\
\hline & & P. scolyti Evans & 8.14 & 5.03 \\
\hline & & $\begin{array}{l}\text { P. holoventris Moraes, Britto, } \\
\text { Mineiro \& Halliday }\end{array}$ & 3.73 & 1.59 \\
\hline & & P. pygmaeus (Müller) & 0.68 & 1.85 \\
\hline & & P. aegyptiacus Nasr & 1.36 & 1.59 \\
\hline & Pachylaelapidae & Pachylaelaps reticulates Berlese & 3.73 & 0.26 \\
\hline & \multirow{8}{*}{$\begin{array}{l}\text { Blattisociidae } \\
\text { German }\end{array}$} & Lasioseius lindquisti Nasr and Abou- Awad & 7.79 & 4.23 \\
\hline & & L. parberlesei Bhattacharyya & 1.69 & 3.17 \\
\hline & & L. egypticus Afifi & 1.69 & 1.06 \\
\hline & & L. africanus Nasr & 2.71 & 1.06 \\
\hline & & L. pencilliger Nasr & 1.36 & 1.06 \\
\hline & & Blattisocius tarsalis Berlese & 3.39 & 0.26 \\
\hline & & B. keegani Fox & 0.34 & 3.17 \\
\hline & & B. mali Oudemans & 4.07 & 2.65 \\
\hline & \multirow{2}{*}{$\begin{array}{l}\text { Macrochelidae } \\
\text { Vitzthum }\end{array}$} & Macrocheles muscaedomesticae (Scopoli) & 2.37 & 0.26 \\
\hline & & M. africanus Hafez, El-Badry \& Nasr & 2.71 & 0.53 \\
\hline & \multirow{6}{*}{$\begin{array}{l}\text { Laelapidae } \\
\text { Berlese }\end{array}$} & Ololaelaps bregetovae Shereef and Soliman & 2.03 & 0.00 \\
\hline & & Androlaelaps casalis (Berlese) & 5.42 & 6.08 \\
\hline & & Hypoaspis sardoa Berlese & 0.68 & 2.91 \\
\hline & & Hypoaspis baloghi Shereef and Afifi & 6.44 & 5.29 \\
\hline & & Hypoaspis lubrica Voigts \& Oudemans & 6.77 & 3.70 \\
\hline & & Pneumolaelaps lubricus (Oudemans \& Voights) & 0 & 2.65 \\
\hline & \multirow[t]{2}{*}{ UropodidaeBerlese } & Uroobovells (Fuscuropoda) Krantzi & 2.71 & 0.79 \\
\hline & & Chiropturopoda bakeri Zaher\&Afifi & 10.51 & 24.34 \\
\hline & $\begin{array}{l}\text { Digamasellidae } \\
\text { Evans }\end{array}$ & Digamasellus presepum Berlese & 4.07 & 0.79 \\
\hline & $\begin{array}{l}\text { Haemogamasidae } \\
\text { Oudemans }\end{array}$ & Haemogamasus pontiger (Berlese) & 9.83 & 30.69 \\
\hline
\end{tabular}


Table 1. Cont.

\begin{tabular}{|c|c|c|c|c|}
\hline \multirow{2}{*}{$\begin{array}{c}\text { Acari } \\
\text { Sub - orders }\end{array}$} & \multirow{2}{*}{ Family } & \multirow{2}{*}{ Mite species } & \multicolumn{2}{|c|}{$\begin{array}{l}\text { Dominance of } \\
\text { mite species }\end{array}$} \\
\hline & & & $\begin{array}{c}\text { Sharkei } \\
\text { a }\end{array}$ & $\begin{array}{c}\text { Beheir } \\
\quad \text { a }\end{array}$ \\
\hline \multirow[t]{24}{*}{ Prostigmata } & \multirow[t]{3}{*}{ Eupodidae Koch } & $\begin{array}{l}\text { Cocceupodes strandtmanni Abou-Awad } \\
\text { and El-Bagoury }\end{array}$ & 3.32 & 1.23 \\
\hline & & Eupodes momeni Abou-Awad & 1.83 & 2.96 \\
\hline & & Eupodes voxencollinus Sig Thor & 0.83 & 0.99 \\
\hline & \multirow[t]{2}{*}{$\begin{array}{l}\text { Rhagidiidae } \\
\text { Oüdemans }\end{array}$} & $\begin{array}{l}\text { Neothoria niloticus Abou-Awad } \\
\text { and El-Bagoury }\end{array}$ & 7.64 & 10.86 \\
\hline & & Roubustocheles mucronata Zacharda & 0.33 & 3.46 \\
\hline & \multirow[t]{2}{*}{ Bdellidae Duges } & Bdellodes longirostris (L.) & 0.33 & 2.22 \\
\hline & & Cyta latirostris (Hermann) & 0.17 & 2.72 \\
\hline & \multirow[t]{3}{*}{ Cunaxidae Thor } & Cunaxa spp. & 0.66 & 1.98 \\
\hline & & C. potchensis Den Heyer & 1.00 & 1.48 \\
\hline & & Doctyloscirusdolichosctosus Den Heyer & 0.17 & 3.46 \\
\hline & \multirow[t]{2}{*}{ Chyletidae leach } & Chyletogenus ornatus (Can. \&Fanz.) & 0.17 & 4.44 \\
\hline & & Cheyletus badryi Zaher and Hassan & 1.02 & 3.46 \\
\hline & \multirow{2}{*}{$\begin{array}{l}\text { Raphignathidae } \\
\text { Kramer }\end{array}$} & Raphignathus gracilis (Rack) & 1.49 & 0.26 \\
\hline & & R. bakeri Zaher \& Gomaa & 3.49 & 2.47 \\
\hline & Smarididae Kramer & Tichosmaris jacoti (Southcot) & 1.01 & 2.22 \\
\hline & \multirow{6}{*}{$\begin{array}{l}\text { Stigmaeidae } \\
\text { Oüdemans }\end{array}$} & Apostigmaeus navicella Grandjean & 8.80 & 18.27 \\
\hline & & Ledermuelleriopsis dendritus Willmann & 6.31 & 8.39 \\
\hline & & Mediolata aegyptiaca Zaher \& Soliman & 9.97 & 8.88 \\
\hline & & M. pentascuta Zaher \& Gomaa & 6.31 & 2.22 \\
\hline & & Agistemus banksi Gomaa \& Hassan & 2.99 & 9.38 \\
\hline & & Agistemus vulgaris Soliman \& Gomaa & 6.81 & 7.41 \\
\hline & \multirow[t]{3}{*}{ Tydeidae Kramer } & Tydeius sp. & 2.66 & 0.74 \\
\hline & & Paralorryia gizai El Bagoury & 2.49 & 3.95 \\
\hline & & Lorrryia reticulate Oudemans & 1.83 & 2.22 \\
\hline \multirow{2}{*}{$\begin{array}{l}\text { Crypto } \\
\text { stigmata }\end{array}$} & Oribatulidae Thor & Scheloribates laevigatus (Koch) & 50.47 & 191.49 \\
\hline & $\begin{array}{l}\text { Oppiidae } \\
\text { Grandjean }\end{array}$ & Oppia sticta Popp & 1.13 & 0.00 \\
\hline \multirow[t]{3}{*}{ Astigmata } & \multirow[t]{2}{*}{ Acaridae Leach } & Tyrophagus putrescentiae (Schrank) & 46.38 & 28.85 \\
\hline & & Rhizoglyphus robini Claparede & 26.09 & 33.65 \\
\hline & Pyroglyphidae & Dermatophagoides farina (Hughes) & 27.54 & 37.5 \\
\hline
\end{tabular}




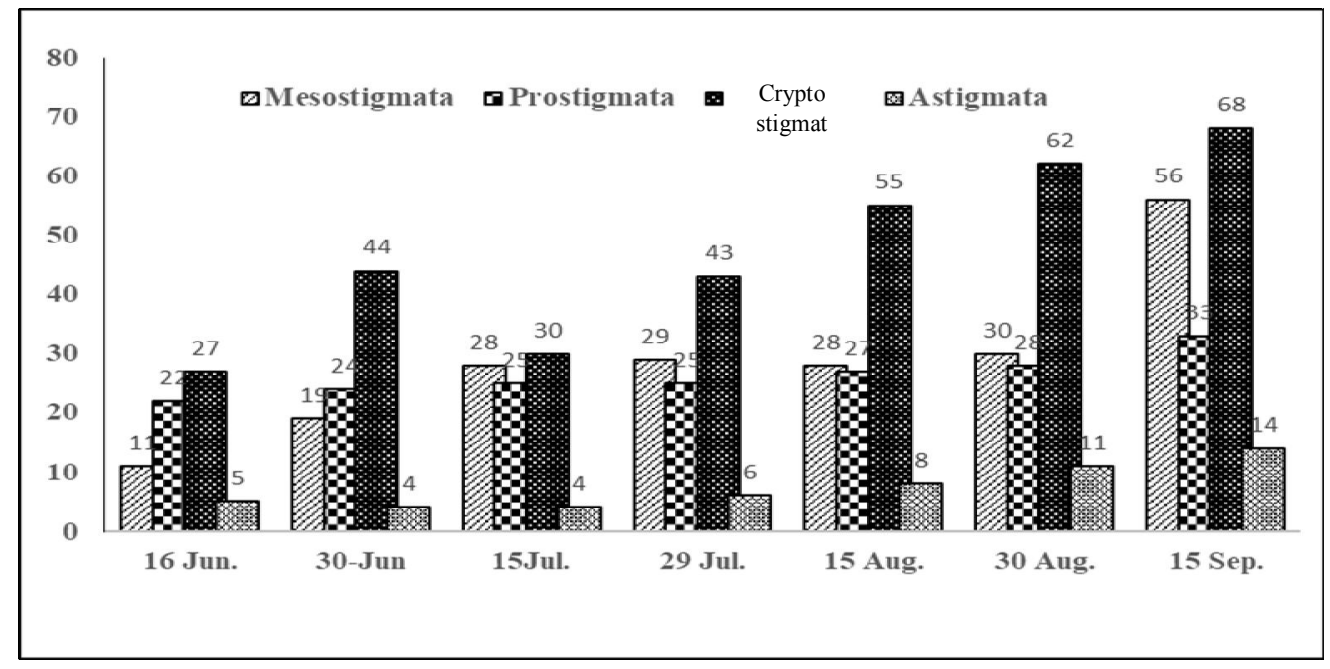

a. Sharkeia

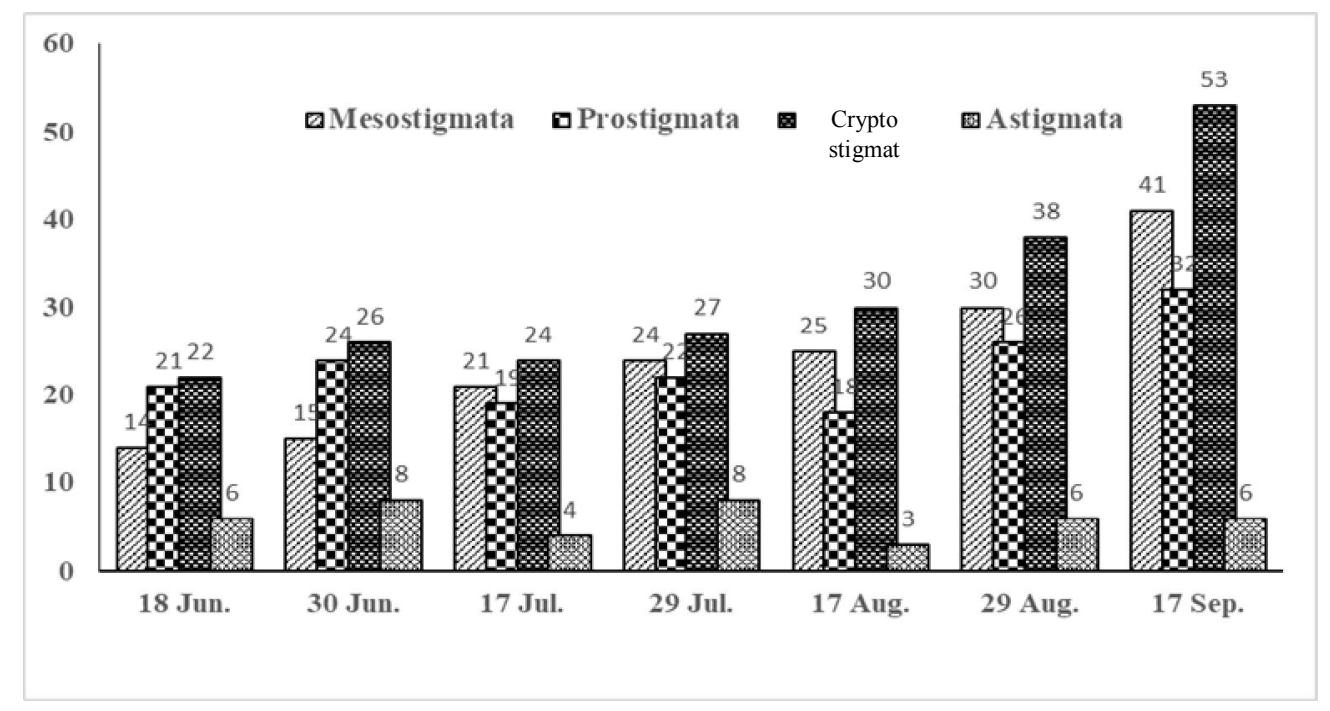

b. Beheira

Fig. (1, a-b): Total numbers of the collected soil mites associated with soybean plants in Sharkeia and Beheira Governorates. 


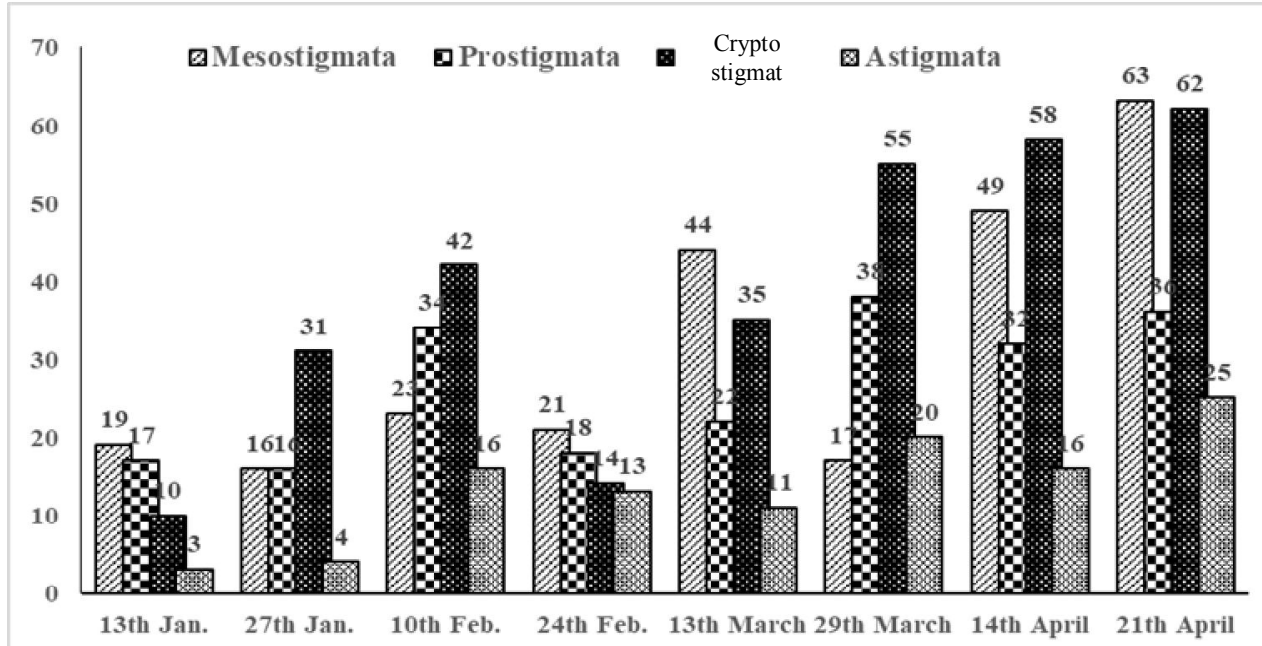

a- Sharkeia

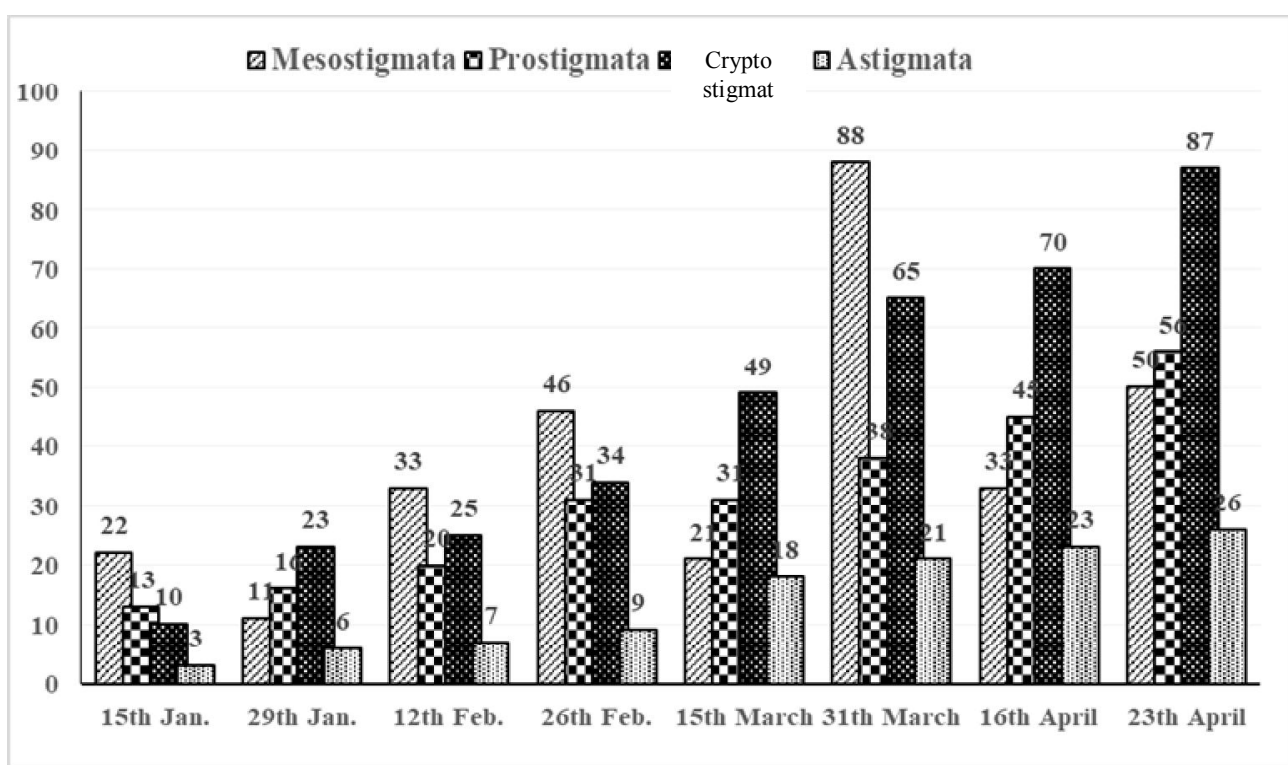

\section{b- Beheira}

Fig. (2, a-b): Total numbers of the collected soil mites associated with wheat plant in Sharkeia and Beheira Governorates.

Sub-order Cryptosstigmata was represented by two families Oribatulidae and Oppiidae which were represented by a single mite species namely: Scheloribates laevigatus (Koch) and Oppia sticta Popp, respectively. While, sub - order Astigmata was represented by two families; Acaridae which represented by two mite species namely; Tyrophagus putrescentiae (Schrank) and Rhizoglyphus robini Claparede and family Pyroglyphidae was represented by a single mite species namely Dermatophagoides farina (Hughes). The obtained data revealed that oribatid mite, 
Scheloribates laevigatus (Koch) was the most dominant mite species recorded 191.49 and $40.47 \%$ in Beheira and Sharkeia, respectively, followed by astigmatid mite, Tyrophagus putrescentiae recorded $46.38 \%$ at Sharkeia and Rhizoglyphus robini recorded $33.65 \%$ in Beheira and mesostigmatic mite Haemogamasus pontiger recorded $24.34 \%$ recorded with $30.69 \%$ for for Chiropturopoda bakeri in Sharkeia Governorate, while the low dominance mite species recorded with Prostigmatid with $18.27 \%$ for Apostigmaeus navicella in Beheira Governorate. Thus, author detected that Cryptostigmatid and Mesostigmatid mite species exhibited the higher number at wheat crop followed by Prostigmatid and Astigmatid mite species, while the low numbers of mite species were recorded at soybean crop and these may be related to crop rotation and biodiverstiy of ecosystem.

Data in Tables ( $2 \& 3$ ) revealed that the number of soil mites inhabiting soil in Sharkeia was more than that recorded in Beheira represented by 56 and 55 mite species, respectively. The diversity of soil mites expressed by Shannon index $\left(\mathrm{H}^{\prime}\right)$, while richness by Evenness ( $\left.\mathrm{J}^{\prime}\right)$, soil in Sharkeia recorded 2.99 and 0.74 respectively, were higher than those obtained in Beheira soil, 2.66 and 0.66 respectively. In despite of the number of soil mites, observed at wheat and soybean soil gave the same value (four sub-orders), the total mite individuals recorded in wheat soil (1345 individuals) was more than in soybean soil (1315 individuals) resulting the increase in diversity and Evenness ( 0.366 and 0.264 , respectively), in case of wheat than in soybean soil (0.299 and 0.216, respectively), (Table 3 ).

As general trend, both diversity and Evenness were positively correlated with number of mite species.

Table 2. Number of species (S), species diversity (Shannon index, $\mathrm{H}^{\prime}$ ) and evenness $\left(\mathrm{J}^{\prime}\right)$ of soil mites inhibited soybean and wheat under different habitats in Sharkeia and Beheira Governorates

\begin{tabular}{|l|c|c|}
\hline \multirow{2}{*}{\multicolumn{1}{c|}{ Parameters }} & \multicolumn{2}{c|}{ Habitats } \\
\cline { 2 - 3 } \cline { 2 - 3 } & Sharkeia & Beheira \\
\hline Species Richness (S) & 56 & 55 \\
\hline Number of Individuals (N) & 1105 & 1494 \\
\hline Shannon Index (H') & 2.99 & 2.66 \\
\hline Evenness $\left(\mathrm{H}^{\prime} / \ln (\mathrm{S})\right)$ & 0.74 & 0.66 \\
\hline
\end{tabular}


Table 3. Number of species (S), species diversity (Shannon index, $\mathrm{H}^{\prime}$ ) and evenness $\left(\mathrm{J}^{\prime}\right)$ of soil mites inhibited under different habitats

\begin{tabular}{|l|c|c|}
\hline \multicolumn{1}{|c|}{ Parameters } & \multicolumn{2}{c|}{ Habitats } \\
\cline { 2 - 3 } & Wheat & Soybean \\
\hline Species Richness (S) & 4 & 4 \\
\hline Number of Individuals (N) & 1345 & 1315 \\
\hline Shannon Index (H') & 0.366 & 0.299 \\
\hline Evenness (H'/ln(S)) & 0.264 & 0.216 \\
\hline
\end{tabular}

The authors Wasylik, 1975 and Abo-Korah \& Osman, 1979 mentioned that different mite species of soil differ in their response to certain plants under which they live and carry out their activities. The obtained results are in agreement with Walia and Mathur (1994) who found that cryptostigmatid mites were the most frequent and abundant followed by Astigmata, Mesostigmata and Prostigmata in survey of soil samples under field crops, vegetable plants, fruit trees and forest plantation. Also, Banerjee (1986); Krantz and Walter 2009; El-Kady and Bahgat 2000; Embarak and Abou El-Saad (2010), reported that cryptostigmatid mites were the most predominant over other groups of mites such as Mesostigmata, Prostigmata and Astigmata, these may be based on host plant. In addition, El-Kawas et al., (2011) investigated the occurrence and distribution of soil mites inhabiting onion and garlic plants in Sharkeia governorate. Twenty-three mite species belonging to four sub-orders were recorded. Results cleared that actinedid and oribatid mites were the most dominant in onion and garlic soils contributing by 35.16 and $41.38 \%$ of the total collected mites, respectively.

\section{REFERENCES}

1. Abo-Korah, S.M. and Osman, A.A. 1979. Seasonal variation of mites population density under certain field crops. $3^{\text {rd }}$ Pest Conf., Tanta Univ., 1: 377-381.

2. Banerjee, S. 1986. Distribution of Acari in relation to soil conditions in 24pargenes, West Bengal, India. VII. International Congress of Acarology, Abst.: page 7.

3. Beaulieu, F. and Walter, D. E. 2007. Predation in suspended and forest floor soils: observation on Australian Mesostigmatic mites. Acarologia, XL. VII (1-2): 43-54.

4. Ducarme, X. and Lebrun, P. 2004. Spatial micro distribution of mites and organic matter in soils and caves. Biol. Fertil. Soils. 39:457-466.

5. El-Kady, G.A. and Bahgat, I. M. 2000. Mites of Sinai Peninsula, III: Incidence and seasonal abundance of soil mites in North and South Sinai. Bull. Ent. Soc. Egypt, 78, 63-76.

6. El-Kawas, H.M.G.; Mead, Hala, M. and El-Sharabasy, H.M. 2011. Occurrence of soil mites in relation to soil analysis at Sharkeia Governorate. Acarines, 5: 41-46. 
7. Embarak, M.Z. and Abou El-Saad, A. K. 2010. Survey of insects and mites inhabiting leaves and soil of Lantana camara L. in Assiut Governorate. Assiut. Univ. Bull. Environ. Res., 13(1): 35-44.

8. Evans, G.O. 1992. Principles of Acarology. C.A.B. International Walling Ford, 522pp.

9. Gilyarov M.S. 1975. An Identification Keys of Soil Living Mites (Sarcoptiformes). Science, Moscow. 491 p. (in Russian

10. Hairiah, K.W.; Hignell, S.E.; Swift, I.M. and Noordwijk, M. 2001. Effects of land use change on belowground biodiversity. Bogor. Internat. onal Center of Research in Agroforestry, $32 \mathrm{pp}$.

11. Krantz, G.W. and Walter, D. E. 2009. A Manual of Acarology. Texas Tech Univ. Press, $807 \mathrm{pp}$.

12. Koehler, H.H. and Prer, H.H. 1999. Predator mite (Gamasina. Mesostigmata) Agriculture Ecosystem and Environment. 74. 395-410.

13. Lasebikan, B.A. 1974. A preliminary communications on micro arthropods from a tropical rain forest in Nigeria. Pedobiologia, Jena, 14: 402-411.

14. Minor, M.A. and Norton, R.A. 2004. Fleets of soil amendments on the assemblages of soil mites (Acari: Oribatida. Mesostigmata) in short rotation willow plantings in Central New York. Canadian. Journal of Forestry Research. 34. 1417-1425.

15. Peterson, H. and Luxton, M. 1982. Comparative analysts of soil fauna population and their role in decomposition processes. Oikos, 39: 287-388.

16. Pielou, E.C. 1984. The Interpretation of Ecological Data: A Primer on Classification and Ordination. J. Wiley and Sons. Singapore. 263 pp.

17. Walia, K. and S. Mathur 1994. Acarina fauna of arable soils and their screening for nematophagy. Indian J. of Nematology, 24(1): 69-79.

18. Walter, D.E. and Proctor, H.C. 1999. Mites Ecology, Evolution and Behaviour. Sydney: Unv. New South Wales Press 1td.

19. Wasylik, A. 1975. The mites (Acarina) of potato and rye field in environs of Choryn, Pol. Ecol. Stud., 1(3): 83-91.

20. Zaher, M. A. (1986a): Survey and ecological studies on phytophagous, predaceous and soil mites in Egypt. I- Phytophagous mites in Egypt (Nile valley and Delta). PL-480 Program. USA Project No. EG- ARS-30. Grant No. FG-EG-139, $228 \mathrm{pp}$.

21. Zaher, M. A. (1986b): Survey and ecological studies on phytophagous, predaceous and soil mites in Egypt. II- Predaceous and non-phytophagous mites (Nile valley and Delta). PL-480 Program. USA Project No. EG- ARS-30. Grant No. FG-EG-139, 567 pp. 


\title{
التنوع البيولوجي لأكاروسات التربة المرتبطه لمحصولي القمح وفول الصويا بمحافظتي الثرقية والبحيرة
}

\author{
فاطمة شحاته قلموش ، عصام محمد عبد السلام ياسين
}
قسم بحوث أكاروس القطن و المحاصيل - معهد بحوث وقاية النباتات- مركز البحوث الزراعية - الدقى - جيزة - مصر

تم حصر ودراسة أكاروسات التربة المصاحبة لنباتات القمح و فول الصويا بمحافظتي

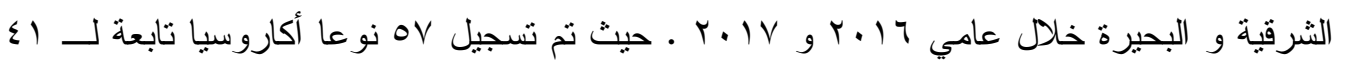

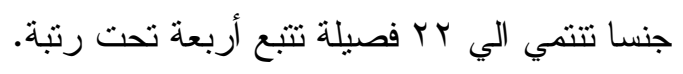

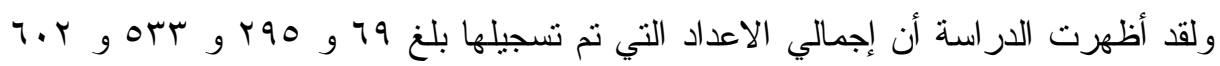

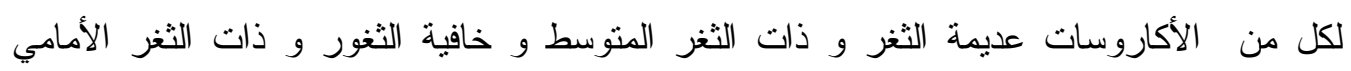

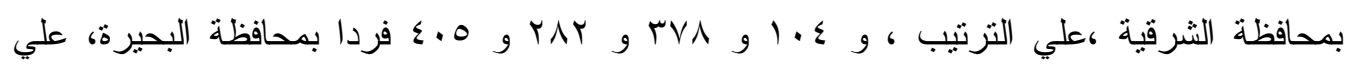

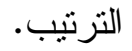

وأوضحت الدراسة أن أعلي تعداد من أكاروسات النزبة في محصول القمح مقارنة بفول الصويا، حيث أظهرت أن تعداد مجموعة الحلم خافية الثغور و مجموعة ذات الثغر المتوسط عالية

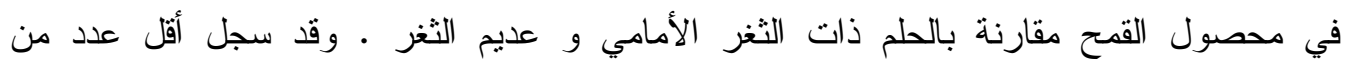
اكاروسات التربة مصاحبة لمحصول فول الصويا. 
